\title{
Evaluation of egg quality parameters of two Hungarian ostrich populations
}

\author{
Lili Dóra Brassó ${ }^{1,2}$ - István Komlósi² \\ ${ }^{1}$ University of Debrecen, Doctoral School of Animal Science \\ ${ }^{2}$ University of Debrecen, Faculty of Agricultural and Food Sciences and Environmental Management Department of Animal Breeding \\ Debrecen, Böszörményi Street 138. \\ brasso.dora@agr.unideb.hu
}

\begin{abstract}
SUMMARY
The aim of our study was to evaluate the quality parameters, porosity and weight loss of eggs deriving from the two most significant ostrich farms in Hungary. Quality parameters included weight, length, width, shape index, egg volume, surface area, circumference and shell volume. The effect of storage conditions in both farms and the incubation technology on egg weight loss in farm " $A$ " were also examined. The research objective was to impart a comprehensive knowledge on egg quality parameters of the main ostrich populations in Hungary and to compare the trios and the farms with each other and the international literature. We could reveal significant differences between trios in all egg quality traits. In conclusion, the shorter and the narrower the eggs were, the more spherical shape they had. Narrower eggs showed smaller surface area, volume, circumference and shell volume and vice versa. Eggs from farm " $B$ " indicated significantly greater width, shape index, surface area, circumference and shell volume than farm " $A$ ". A significant difference was observed in weight loss during storage between the farms. Weight loss in farm " $A$ " was a multiple of farm " $B$ ". In farm " $B$ ” there was a weak, positive correlation between storage period and weight loss $(r=0.22, P \leq 0.05)$, in farm “ $A$ ” it was not significant $(P=0.52)$. There was no relationship between the initial egg weight and weight loss either in farm " $A$ " or farm " $B$ " $(P=0,21, P=0,69)$. A slight positive correlation could be noted between egg porosity and weight loss $(r=0.24$, $P \leq 0.05)$. Pores count presented here was less than the international results. Poultry eggs contain the most pores at the blunt end, less via the equator and the least at the pointed end. In ostrich egg we found more pores via the equator against the blunt end. To draw more precise conclusions, further investigation should be carried out on porosity. Considering the fact that the length of storage period and the weight loss during incubation are in strict correlation with hatchability, we intend to extend our research aims to these traits.
\end{abstract}

Keywords: ostrich breeding in Hungary; egg production; egg quality parameters; egg storage; egg incubation

\section{INTRODUCTION}

Egg quality parameters have been examined mostly in poultry species so far. Knowing egg shape index is necessary for testing shell stiffness (Nedomová et al., 2009) and is vital for the arithmetic simulation of egg response to mechanical and thermal effects (Perianu et al., 2010; Denys et al., 2003). Egg volume and surface area are the two main geometric calculations applied for the description of populations and for ecologicalmorphological evaluations. These parameters are also used to predict chick weight, hatchability, shell quality and egg internal value (Nedomová and Buchar, 2013). The length of storage period, weight loss during storage and incubation is relevant from the aspect of hatchability and chick quality. Longer storage period often occurs due to incubation management and the unpredictable market conditions. International literature states that storage period of more than 10 days significantly reduces hatchability and eggs stored for more than 17 days do not hatch (Deeming, 1996). Hassan et al. (2005) suggested that eggs stored for longer than 10 days had better hatchability, than those stored for 15-24 days, but storage period between 1015 days did not differ from eggs stored either for 10 or 15 days. 15 days of storage significantly increased incubation period and chick weight. However, Nahm (2001) indicated that storage period did not significantly affected hatchability of eggs stored at $15.5{ }^{\circ} \mathrm{C}$ for 19 days. Weight loss during storage and incubation is known to be influenced by egg pores count, pores diameter and its distribution can be different in each part of the egg. In the paper we aimed to determine the correlation between egg surface area and weight loss and to define pores count at different parts of the egg depending on initial egg weight. Our purpose was to present egg quality parameters of the two significant ostrich farms in Hungary. Our indices were compared to the international results.

\section{MATERIALS AND METHODS}

The research was carried out at two Hungarian ostrich farms with an average 50 breeders. In farm " $A$ " 16 females, from farm "B" 14 females took part in the investigations with a total egg number of 176 . Company's names are hidden in the publication due to the protection of personal rights, instead we address them as "farm A" and "farm "B". After collection, workers cleaned and sanitized the eggs with a $1 \% \mathrm{cc}$. Virocid sol, then placed them in the storage room. In farm " $A$ " the temperature and relative humidity were varying between $18-22{ }^{\circ} \mathrm{C}$ and $40-50 \%$. In farm " $\mathrm{B}$ " storage temperature was constantly $16{ }^{\circ} \mathrm{C}$ with $40 \%$ relative humidity. Incubation temperature in farm " $\mathrm{A}$ " was $36.5{ }^{\circ} \mathrm{C}$ with relative humidity of between 20-50\%. International papers indicate $35.5-37{ }^{\circ} \mathrm{C}$ incubation temperature with $25-50 \%$ relative humidity (Hassan et al., 2005; Nahm, 2001).

The following indices were examined:

- Initial egg weight $(\mathrm{g})$

- Length, width (cm)

- Shape index $(\%)$ 
- Egg volume $\left(\mathrm{cm}^{3}\right)$

- Surface area $\left(\mathrm{cm}^{2}\right)$

- Circumference $(\mathrm{cm})$

- Egg volume $\left(\mathrm{cm}^{3}\right)$

- Porosity (pores count $/ \mathrm{cm}^{2}$ )

- Weight loss during storage and incubation $(\mathrm{g})$.

Initial egg weights on farm " $\mathrm{B}$ " were measured by workers. From farm "A" no initial weights have been measured, so the paper does not contain these data. Each quality index was calculated by the following formulas (Nedmová and Buchar, 2013), using length and width data taken by us with a two decimal accuracy caliper.

Shape index $=($ width/length $) * 100$

Volume $=\pi / 6 *$ length $*$ width

Surface area $=\pi *$ width $^{2}$

Circumference $=\pi *$ width

Shell volume $=$ surface are/length

Pores count was measured by the method of ElSafty (2012) using a 3-centimeter-wide and 11-centimeter-long plastic tape measure with four equidistant 1-square-centimeter cuts in it. The tape measure was placed on the outside egg surface at the equator and at the center of the blunt end, so we could count the number of pores at five points. The procedure was carried out by using a candling lamp and a magnifying glass. Egg weights for weight loss were measured with a calibrated digital scale of 5-gramm- accuracy. Sizes and weights were taken between 2020 May and September.

All data were evaluated by Microsoft Office Excel and SPSS 23.0. Trios on each farm and farms were compared applying univariate analysis. Egg weight loss was examined on eggs of various ages. We used correlation and regression analysis to determine the relationship between egg weight and egg surface area, egg weight and porosity, egg surface area and porosity, porosity and weight loss, egg age and weight loss, storage period and weight loss and time spent between weighing during incubation and weight loss.

\section{RESULTS AND DISCUSSION}

Average egg length was $15.21 \mathrm{~cm}$, width showed $12.69 \mathrm{~cm}$ and shape index was $83.51 \%$. Trio 1 had the shortest eggs $(14.69 \mathrm{~cm})$, trio 4 laid the longest ones $(15.84 \mathrm{~cm})$. The narrowest eggs were found in trios 1 , 2,3 and $5(12.51,12.65,12.52 \mathrm{~cm}$ and $12.43 \mathrm{~cm})$ and the widest ones were laid by trios 6,7 and $8(12.86$, 13.00 and $13.07 \mathrm{~cm}$ ). Expressing width in the ratio of length, eggs from trio 1 showed the most spherical shape $(85.28 \%)$. The phenomenon can be explained simply, since the shortest and narrowest eggs were measured in trio 1 , so in this case width stood the closest to the length. Eggs from trio 4 were the most egg-shaped with an index of $80.37 \%$. Table 1 and Table 2 present the egg quality parameters of farm "A".

Table 1. Egg length, width and shape index in farm " $\mathrm{A} "$

\begin{tabular}{cccc}
\hline \multirow{2}{*}{ Trios } & Length $(\mathbf{c m})$ & Width $(\mathbf{c m})$ & Shape index $(\%)$ \\
\cline { 2 - 4 } & & Mean and standard error & \\
\hline $1(\mathrm{n}=14)$ & $14.69 \pm 0.12^{\mathrm{d}}$ & $12.51 \pm 0.07^{\mathrm{a}}$ & $85.28 \pm 0.67^{\mathrm{b}}$ \\
$2(\mathrm{n}=14)$ & $15.11 \pm 0.12^{\mathrm{ab}}$ & $12.65 \pm 0.07^{\mathrm{ab}}$ & $83.74 \pm 0.67^{\mathrm{abc}}$ \\
$4(\mathrm{n}=13)$ & $14.95 \pm 0.13^{\mathrm{bd}}$ & $12.52 \pm 0.07^{\mathrm{ab}}$ & $83.81 \pm 0.73^{\mathrm{abc}}$ \\
$5(\mathrm{n}=6)$ & $15.84 \pm 0.14^{\mathrm{e}}$ & $12.73 \pm 0.08^{\mathrm{bc}}$ & $80.37 \pm 0.80^{\mathrm{d}}$ \\
$6(\mathrm{n}=9)$ & $15.02 \pm 0.20^{\mathrm{abd}}$ & $12.43 \pm 0.10^{\mathrm{a}}$ & $82.78 \pm 1.12^{\mathrm{abcd}}$ \\
$7(\mathrm{n}=8)$ & $15.38 \pm 0.15^{\mathrm{ac}}$ & $12.86 \pm 0.08^{\mathrm{cd}}$ & $83.71 \pm 0.84^{\mathrm{abc}}$ \\
$8(\mathrm{n}=5)$ & $15.74 \pm 0.15^{\mathrm{ce}}$ & $13.00 \pm 0.09^{\mathrm{d}}$ & $82.64 \pm 0.89^{\mathrm{acd}}$ \\
\hline Great mean $(\mathbf{n = 7 9})$ & $15.32 \pm 0.20^{\mathrm{abc}}$ & $13.07 \pm 0.11^{\mathrm{d}}$ & $85.33 \pm 0.01^{\mathrm{abc}}$ \\
\hline
\end{tabular}

a,b,c,d,e $\mathrm{p} \leq 0.05$ Different letters represent significant differences

Table 2. Egg volume, surface area, circumference and shell volume of eggs in farm " $A$ "

\begin{tabular}{ccccc}
\hline \multirow{2}{*}{ Trios } & Volume $\left(\mathbf{c m}^{\mathbf{3}}\right)$ & Surface area $\left(\mathbf{c m}^{\mathbf{2}}\right)$ & Circumference $\left(\mathbf{c m}^{2}\right)$ & Shell volume $\left(\mathbf{c m}^{\mathbf{3}}\right)$ \\
\cline { 2 - 5 } & \multicolumn{4}{c}{ Mean and standard error } \\
\hline ( $(\mathrm{n}=14)$ & $1205.16 \pm 19.91^{\mathrm{b}}$ & $492.18 \pm 5.14^{\mathrm{a}}$ & $39.31 \pm 0.20^{\mathrm{a}}$ & $33.54 \pm 0.44^{\mathrm{ab}}$ \\
$3(\mathrm{n}=14)$ & $1265.61 \pm 19.91^{\mathrm{ac}}$ & $502.54 \pm 5.14^{\mathrm{ab}}$ & $39.73 \pm 0.20^{\mathrm{ab}}$ & $33.27 \pm 0.44^{\mathrm{a}}$ \\
$4(\mathrm{n}=10)$ & $1229.35 \pm 21.50^{\mathrm{ab}}$ & $492.88 \pm 5.56^{\mathrm{a}}$ & $39.34 \pm 0.22^{\mathrm{a}}$ & $32.97 \pm 0.48^{\mathrm{a}}$ \\
$5(\mathrm{n}=6)$ & $1325.02 \pm 23.55^{\mathrm{cd}}$ & $511.47 \pm 6.09^{\mathrm{bc}}$ & $40.08 \pm 0.24^{\mathrm{bc}}$ & $33.07 \pm 0.52^{\mathrm{a}}$ \\
$6(\mathrm{n}=9)$ & $1214.15 \pm 33.31^{\mathrm{ab}}$ & $485.11 \pm 8.61^{\mathrm{a}}$ & $39.04 \pm 0.34^{\mathrm{a}}$ & $32.32 \pm 0.74^{\mathrm{a}}$ \\
$7(\mathrm{n}=9)$ & $1331.55 \pm 24.83^{\mathrm{d}}$ & $519.65 \pm 6.42^{\mathrm{cd}}$ & $40.40 \pm 0.25^{\mathrm{cd}}$ & $33.83 \pm 0.55^{\mathrm{a}}$ \\
$8(\mathrm{n}=5)$ & $1393.06 \pm 26.33^{\mathrm{d}}$ & $531.08 \pm 6.80^{\mathrm{d}}$ & $40.84 \pm 0.27^{\mathrm{d}}$ & $33.76 \pm 0.59^{\mathrm{ab}}$ \\
\hline Great mean (n=79) & $1374.91 \pm 33.31^{\mathrm{d}}$ & $537.54 \pm 8.61^{\mathrm{d}}$ & $41.07 \pm 0.34^{\mathrm{d}}$ & $35.05 \pm 0.74^{\mathrm{b}}$ \\
\hline
\end{tabular}

a,b,c,d,e $\mathrm{p} \leq 0.05$ Different letters represent significant differences 
Average egg volume was $1281.39 \mathrm{~cm}^{3}$. Trio 1,3 and 5 had the smallest egg volume $(1205.16,1229.35$ and $1214.15 \mathrm{~cm}^{3}$ ) as these eggs were the narrowest of all. Eggs from trio 6, 7 and 8 indicated the greatest volume $\left(1331.55,1393.06\right.$ and $\left.1374.91 \mathrm{~cm}^{3}\right)$. The result comes from the fact that these eggs were the widest, so multiplying width with the , $\pi / 6$ " quotient leads to the largest egg volume. Average surface area was 506.41 $\mathrm{cm}^{2}$. The smallest surface area was calculated in trio 1 , 3 and 5 (492.18, 492.88 and $\left.485.11 \mathrm{~cm}^{2}\right)$, whereas eggs from trio 6, 7 and 8 had the largest surface area (519.65, 531.08 and $537.74 \mathrm{~cm}^{2}$ ). Circumference on average was $39.88 \mathrm{~cm}$. Differences were the same as in the previous cases. Trio 1, 3, 5 had the smallest egg circumference (39.31, 39.34 and $39.04 \mathrm{~cm})$ and trio 8 indicated the largest one, $41.07 \mathrm{~cm}$. Average shell volume showed $33.41 \mathrm{~cm}^{3}$. Trios did not differ significantly, except for trio 8 , having the greatest shell volume of $35.05 \mathrm{~cm}^{3}$. Table 3 and Table 4 present the egg quality parameters of farm "B".

Table 3. Egg weight, length, width and shape index in farm "B"

\begin{tabular}{|c|c|c|c|c|}
\hline \multirow{2}{*}{ Trios } & Egg weight (g) & Length (cm) & Width (cm) & Shape index $(\%)$ \\
\hline & \multicolumn{4}{|c|}{ Mean and standard error } \\
\hline $1(n=10)$ & $1375.10 \pm 28.86^{\mathrm{a}}$ & $15.15 \pm 0.15^{\mathrm{ab}}$ & $12.40 \pm 0.09^{\mathrm{ab}}$ & $81.93 \pm 0.88^{\text {abe }}$ \\
\hline $2(n=13)$ & $1359.08 \pm 25.31^{\mathrm{a}}$ & $14.70 \pm 0.13^{\mathrm{e}}$ & $12.48 \pm 0.08^{\mathrm{ac}}$ & $85.05 \pm 0.77^{\mathrm{d}}$ \\
\hline $3(n=13)$ & $1392.46 \pm 25.31^{\mathrm{a}}$ & $14.82 \pm 0.13^{\mathrm{ae}}$ & $12.46 \pm 0.08^{\mathrm{ab}}$ & $84.08 \pm 0.77^{\text {bd }}$ \\
\hline $4(n=19)$ & $1465.42 \pm 20.94^{\mathrm{b}}$ & $15.44 \pm 0.11^{\mathrm{bc}}$ & $12.55 \pm 0.06^{\mathrm{ac}}$ & $81.37 \pm 0.64^{\text {ace }}$ \\
\hline $5(n=10)$ & $1557.30 \pm 28.86^{\mathrm{c}}$ & $15.70 \pm 0.15^{\mathrm{cd}}$ & $13.02 \pm 0.09^{\mathrm{d}}$ & $83.00 \pm 0.88^{\text {abde }}$ \\
\hline $6(n=17)$ & $1520.29 \pm 22.13^{\mathrm{bc}}$ & $15.94 \pm 0.12^{\mathrm{d}}$ & $12.68 \pm 0.07^{\mathrm{c}}$ & $79.60 \pm 0.68^{c}$ \\
\hline $7(n=17)$ & $1358.82 \pm 22.13^{\mathrm{a}}$ & $15.12 \pm 0.12^{\mathrm{a}}$ & $12.27 \pm 0.07^{\mathrm{b}}$ & $81.19 \pm 0.68^{\text {ace }}$ \\
\hline Great mean $(n=99)$ & $1432.64 \pm 9.44$ & $15.29 \pm 0.05$ & $12.54 \pm 0.03$ & $82.09 \pm 0.29$ \\
\hline
\end{tabular}

a,b,c,d,e $\mathrm{p} \leq 0.05$ Different letters represent significant differences

Average egg weight was $1432.64 \mathrm{~g}$. Eggs from trios 1, 2, 3 and 7 were the lightest, below $1400 \mathrm{~g}$. Trio $4 \mathrm{had}$ eggs of the medium weight category, between 1400 and $1500 \mathrm{~g}$. The heaviest eggs were laid by the females of trios 5 and 6, above $1500 \mathrm{~g}$. Average egg length was $15.29 \mathrm{~cm}$. Trios 2 and 3 had the shortest eggs $(14.70$ and $14.82 \mathrm{~cm})$ and trios 5 and 6 the longest ones $(15.70$ and $15.94 \mathrm{~cm})$. Others showed values around the average. Average egg width was $12.54 \mathrm{~cm}$. Trio 7 laid the narrowest $(12.27 \mathrm{~cm})$, trio 5 the widest $(13.02 \mathrm{~cm})$ eggs. Average egg shape index was $82.09 \%$. Trio 2 and 3 had the most spherical eggs with indices $85.05 \%$ and $84.04 \%$. A width/length percent ratio was the smallest in trio $6,79.60 \%$.

Table 4. Egg volume, surface area, circumference and shell volume of eggs in farm "B"

\begin{tabular}{|c|c|c|c|c|}
\hline \multirow{2}{*}{ Trios } & Volume $\left(\mathrm{cm}^{3}\right)$ & Surface area $\left(\mathrm{cm}^{2}\right)$ & Circumference (cm) & Shell volume $\left(\mathrm{cm}^{3}\right)$ \\
\hline & \multicolumn{4}{|c|}{ Mean and standard error } \\
\hline $1(\mathrm{n}=10)$ & $1221.12 \pm 24.60^{\mathrm{ac}}$ & $483.42 \pm 7.01^{\mathrm{ab}}$ & $38.97 \pm 0.28^{\mathrm{ac}}$ & $31.92 \pm 0.49^{\mathrm{bc}}$ \\
\hline $2(n=13)$ & $1198.98 \pm 21.57^{\mathrm{a}}$ & $489.53 \pm 6.15^{b}$ & $39.21 \pm 0.24^{\mathrm{bc}}$ & $33.36 \pm 0.43^{\mathrm{d}}$ \\
\hline $3(n=13)$ & $1206.02 \pm 21.57^{\mathrm{a}}$ & $487.89 \pm 6.15^{\mathrm{ab}}$ & $39.14 \pm 0.24^{\mathrm{ac}}$ & $32.91 \pm 0.43^{\text {bd }}$ \\
\hline $4(n=19)$ & $1273.71 \pm 17.85^{\mathrm{c}}$ & $494.70 \pm 5.09^{\mathrm{bc}}$ & $39.41 \pm 0.20^{\mathrm{bc}}$ & $32.08 \pm 0.36^{\mathrm{bc}}$ \\
\hline $5(n=10)$ & $1392.60 \pm 24.60^{\mathrm{d}}$ & $532.41 \pm 7.01^{\mathrm{d}}$ & $40.89 \pm 0.28^{\mathrm{d}}$ & $33.96 \pm 0.49^{d}$ \\
\hline $6(n=17)$ & $1345.64 \pm 18.87^{\mathrm{d}}$ & $506.03 \pm 5.38^{c}$ & $39.85 \pm 0.21^{\mathrm{b}}$ & $31.74 \pm 0.38^{\mathrm{c}}$ \\
\hline $7(n=17)$ & $1191.94 \pm 18.87^{\mathrm{a}}$ & $473.10 \pm 5.38^{\mathrm{a}}$ & $38.55 \pm 0.21^{\mathrm{a}}$ & $31.30 \pm 0.38^{\mathrm{c}}$ \\
\hline Great mean $(n=99)$ & $1260.02 \pm 8.05$ & $494.03 \pm 2.29$ & $39.38 \pm 0.09$ & $32.34 \pm 0.16$ \\
\hline
\end{tabular}

Average egg volume was $1260.02 \mathrm{~cm}^{3}$. Eggs from trio 1, 2, 3 and 7 had the smallest egg volume (1198.98 $\mathrm{cm}^{3}, 1206.02 \mathrm{~cm}^{3}$ and $\left.1191.94 \mathrm{~cm}^{3}\right)$. Conversely, trio 5,6 had the greatest egg volume $\left(1392.60 \mathrm{~cm}^{3}\right.$ and $\left.1345.64 \mathrm{~cm}^{3}\right)$. Surface area averaged at $494.03 \mathrm{~cm}^{2}$. The smallest surface area was calculated in trio $1,3,7$ $\left(483.42 \mathrm{~cm}^{2}, 487.53 \mathrm{~cm}^{2}\right.$ and $\left.473.10 \mathrm{~cm}^{2}\right)$, the greatest in trio $5\left(532.41 \mathrm{~cm}^{2}\right)$. Average circumference was $39.38 \mathrm{~cm}$. Trio 7 laid eggs with the smallest $(38.55 \mathrm{~cm})$ and trio 5 with the greatest $(40.89 \mathrm{~cm})$ circumference. Average shell volume was $32.34 \mathrm{~cm}^{3}$. Trio 2, 3, and 5 had the smallest shell volume $(33.36 \mathrm{~cm}, 32.91 \mathrm{~cm}$ and $33.96 \mathrm{~cm})$. Figure 1 demonstrates one-week weight loss of eggs deriving from farm " $\mathrm{A}$ ". 
Figure 1. One-week loss of eggs in farm „A”

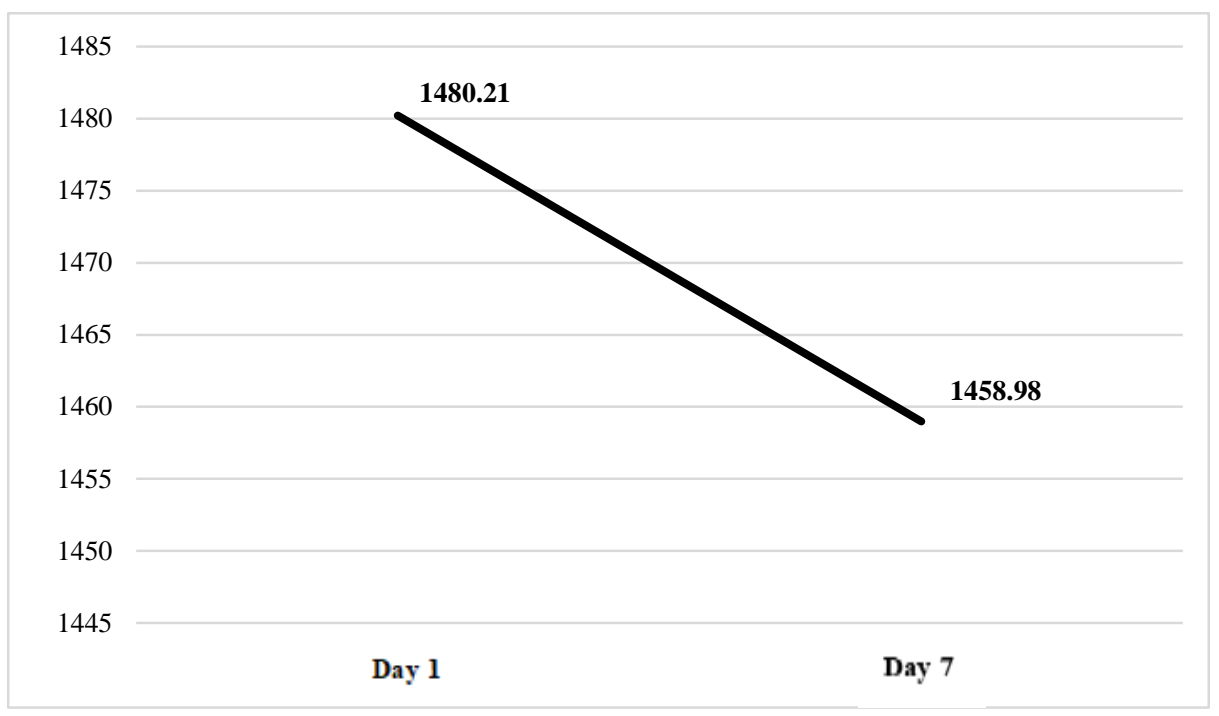

Weight on day 0 indicates the average egg weight at the moment of measurement, not the initial egg weight. The age at the measurement differed, as some eggs were set for the first day, some had been there for many days before weighing, but for not more than 7 days. Egg age was subjected to regression analysis to see if there was a relationship between the variables. Egg age had no significant effect on weight loss during storage $(\mathrm{r}=0.07, \mathrm{P}=0.52)$. One-week egg weight loss was $21.23 \mathrm{~g}$, indicating $3.03 \mathrm{~g}$ loss per day. Figure 2 demonstrates weight loss during incubation in farm "A".

Figure 2. Egg weight loss during incubation in farm ,A”

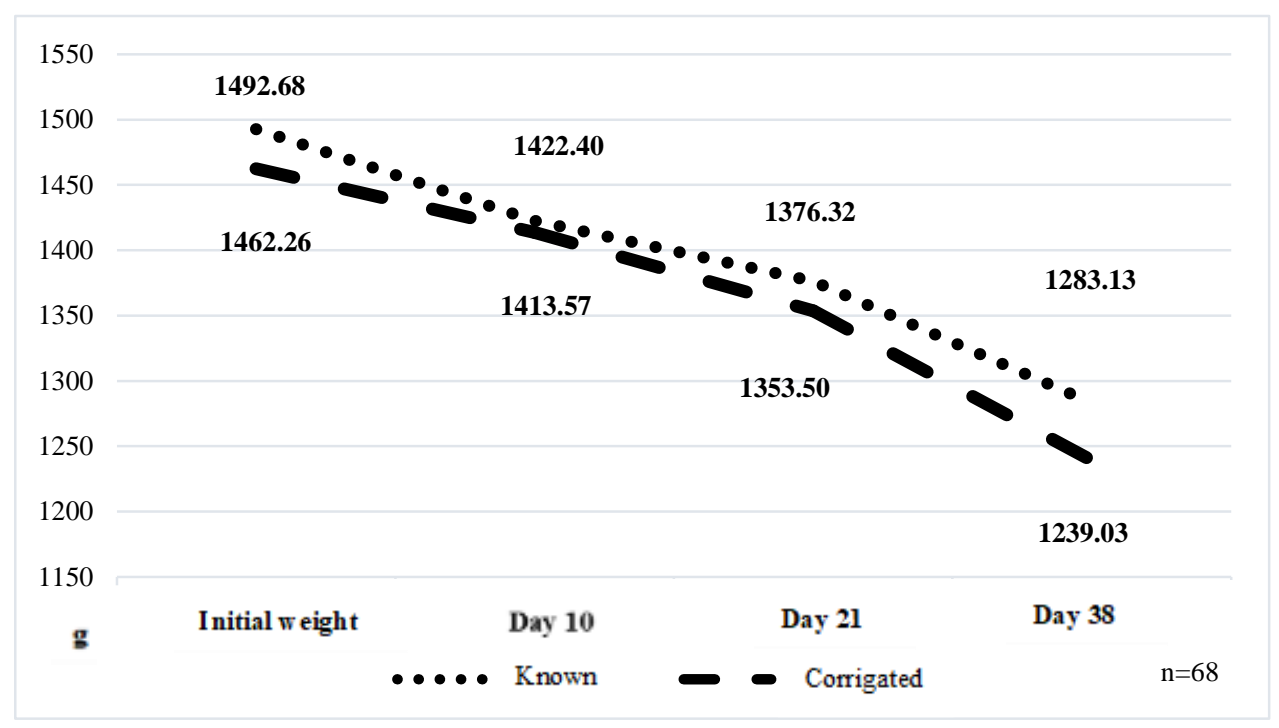

The age of eggs $(\mathrm{r}=0.49, \mathrm{P} \leq 0.05)$ and the date of measure (the $10^{\text {th }}, 21^{\text {st }}$ and $38^{\text {th }}$ day of incubation, $\mathrm{r}=0.53, \mathrm{P} \leq 0.05$ ) significantly influenced weight loss during incubation. The known curve $(n=28)$ shows that in the first period of incubation eggs lost $70 \mathrm{~g}(4.71 \%)$ from their initial weight. In the next eleven days we could observe a 46-g-loss $(3.24 \%)$, then in the second half a 93-g-loss $(6.77 \%)$. During the 38 days of incubation total weight loss was $14.72 \%$. From these results we drew the conclusion that embryo metabolism is the speediest in the first ten days of incubation, when firstly qualitative changes take place (the development of extra-embryonal membranes and apparatus circulatory system, respiratory system, excretory system, digestive system and nervous system). From the second half, quantitative changes of the embryo (an increase in weight, length, width, depth and circumference) take priority over qualitative changes. For the curve below we had to adjust initial weight, since we had no data on it. The correction was made 
according to Figure 1. During storage, the average daily weight loss was $3.03 \mathrm{~g}$. Eggs were set in the same condition, as it was mentioned in the chapter "Materials and methods". Similar storage conditions made it possible to correct weights measured four days before setting in the incubator to the onset of incubation considering the average daily $3.03 \mathrm{~g}$ loss. Table 5 demonstrates egg surface area, pores count and oneweek loss in three different weight groups.

Table 5. Egg surface area, pores count and one-week loss of egg from the different weight categories

\begin{tabular}{|c|c|c|c|c|c|}
\hline \multirow[t]{2}{*}{$\begin{array}{l}\text { Weight categories } \\
\text { (g) }\end{array}$} & $\begin{array}{l}\text { Egg surface area } \\
\qquad\left(\mathbf{c m}^{2}\right)\end{array}$ & $\begin{array}{c}\text { Mean pores } \\
\text { count } \\
\left(\text { pores } / \mathrm{cm}^{2}\right)\end{array}$ & $\begin{array}{c}\text { Mean pores count via } \\
\text { the equator } \\
\left(\text { pores } / \mathbf{c m}^{2}\right)\end{array}$ & $\begin{array}{l}\text { Mean pores count } \\
\text { at the centre of the } \\
\text { aircell (pores } / \mathrm{cm}^{2} \text { ) }\end{array}$ & $\begin{array}{c}\text { One-week } \\
\text { weight loss (g) }\end{array}$ \\
\hline & \multicolumn{5}{|c|}{ Mean and standard error } \\
\hline$\leq 1350 \mathrm{~g}(\mathrm{n}=27)$ & $456.01 \pm 4.29^{\mathrm{a}}$ & $18.12 \pm 1.23$ & $18.53 \pm 1.39$ & $17.36 \pm 1.35$ & $5.48 \pm 2.31$ \\
\hline $1351-1450 \mathrm{~g}(\mathrm{n}=30)$ & $488.99 \pm 4.02^{\mathrm{b}}$ & $19.71 \pm 1.17$ & $20.18 \pm 1.32$ & $18.02 \pm 1.29$ & $5.52 \pm 2.54$ \\
\hline $1451 \mathrm{~g} \leq(\mathrm{n}=24)$ & $516.68 \pm 4.62^{\mathrm{c}}$ & $18.25 \pm 1.30$ & $19.18 \pm 1.47$ & $14.54 \pm 1.44$ & $5.48 \pm 3.07$ \\
\hline Great mean $(n=81)$ & $485.96 \pm 3.56$ & $18.75 \pm 0.71$ & $19.33 \pm 0.80^{\mathrm{a}}$ & $16.77 \pm 0.79^{b}$ & $5.49 \pm 0.28$ \\
\hline
\end{tabular}

$\overline{\mathrm{a}, \mathrm{b}, \mathrm{c}, \mathrm{d}, \mathrm{e}} \mathrm{p} \leq 0.05$ Different letters represent significant differences

Eggs in the smallest weight category had the smallest surface area of $456.01 \mathrm{~cm}^{2}$. Medium eggs showed greater $\left(488.99 \mathrm{~cm}^{2}\right)$ and the largest eggs the greatest surface area $\left(516.68 \mathrm{~cm}^{2}\right)$. Mean pores count did not significantly differ in each weight category $(\mathrm{P}=0.66)$, however, positive, medium relationship could be demonstrated between the porosity of the two examined areas (equator and the blunt end, $r=0.39$, $\mathrm{P} \leq 0.05$ ). Pores count via the equator was 19 pores $/ \mathrm{cm}^{2}$, in the center of the blunt end we found 16 pores $/ \mathrm{cm}^{2}$ with a significant difference $(\mathrm{P} \leq 0.05)$. The result goes against our technical knowledge, since the literature states that the most pores can be detected in the blunt end, less via the equator and the least at the pointed end. In chicken egg this value is between 146-158, 134143 , and $97-108$ pores $/ \mathrm{cm}^{2}$ and in goose 42-56, 36-44 and $29-37$ pores $/ \mathrm{cm}^{2}$ can be observed in the three areas. Considering this correlation, we can assume that the larger the egg is, the less pores it is covered with and the greater the pore diameter is (Bogenfürst, 2017). In our research no relationship could be expressed between surface area and pores count $(\mathrm{P}=0.74)$. Eggs sent different, but not longer than seven days in the storage room. Time passed during storage was in a weak, positive correlation with weight loss $(\mathrm{r}=0.22$, $\mathrm{P} \leq 0.05$ ). Egg weight loss was 5 to $5.5 \mathrm{~g}$ regardless weight category. Initial egg weight and weight loss did not correlate $(\mathrm{P}=0.69)$. A weak positive relationship could be indicated between porosity and weight loss $(\mathrm{r}=0.24, \mathrm{P} \leq 0.05)$.

We did not have data on initial egg weight from farm "A", so we only examined this parameter in case of farm "B". Table 3 showed that in farm " $\mathrm{B}$ " the average initial egg weight was $1432.64 \mathrm{~g}$. Our result was higher than the $1321 \mathrm{~g}$ observed by Mushi et al. (2007), but it was similar to the $1455 \mathrm{~g}$ of Brand et al. (2003). Regarding climate conditions, Benoît et al. (2014) declared that egg weight in wet environment was $1370 \mathrm{~g}$ and showed $1200 \mathrm{~g}$ in drought. In farm "A" the average egg length was 15.21 and $12.69 \mathrm{~cm}$ (Table 1) and in farm "B" these traits showed 15.29 and 12.54 $\mathrm{cm}$ (Table 4). On the basis of length there was no significant difference between farms $(\mathrm{P}=0.39)$, however, eggs differed in width $(\mathrm{P} \leq 0.05)$. Cooper et al. (2001) found ostrich egg length and width to be 15.24 $\mathrm{cm}$ and $12.70 \mathrm{~cm}$, respectively. Egg shape index in farm "A" was $83.51 \%$ (Table 1), in farm "B" showed $82.09 \%$ (Table 3). There was a significant difference between farms in this parameter $(\mathrm{P} \leq 0.05)$. Nedomová and Buchar (2013) claimed that the average egg length, width and shape index were $14.66 \mathrm{~cm}, 12.56 \mathrm{~cm}$ and 82.49\%. Elsayed (2009), Koutinhouin et al. (2014), Benoît et al. (2014) and Selvan et al. (2014) stated that egg shape was $80 \%, 83.5 \%, 82.49 \%$ and $82.86 \%$, respectively. Average egg volume in farm „A" was $1281.39 \mathrm{~cm}^{3}$ (Table 2), in farm „B” it was observed $1260.02 \mathrm{~cm}^{3}$ (Table 2). There was no significant difference between farms $(\mathrm{P}=0.16)$. Moreki et al. (2016) had $1116.12 \mathrm{~cm}^{3}$ for average egg volume in his research. This value is less than the one we found. In farm " $A$ " the average egg surface area was $506.41 \mathrm{~cm}^{2}$ (Table 2) and in farm "B" showed $494.03 \mathrm{~cm}^{2}$ (Table $4)$. There was a significant difference between farms $(\mathrm{P} \leq 0.05)$. Nedomová and Buchar (2013) calculated egg surface $464.97 \mathrm{~cm}^{2}$. Their result was less than ours. Average egg circumference in farm "A" was $39.88 \mathrm{~cm}$ (Table 2), in farm "B" showed $39.38 \mathrm{~cm}$ (Table 4). There was a significant difference between farms in this parameter $(\mathrm{P} \leq 0.05)$. Elobeid et al. (2010) had $40.35 \mathrm{~cm}$ for circumference, which is slightly greater than that we found in Hungary. The average $33.41 \mathrm{~cm}^{3}$ shell volume in farm "A" (Table 2) was significantly larger $(\mathrm{P} \leq 0.05)$ than the $32.34 \mathrm{~cm}^{3}$ in farm "B" (Table 4). One-week weight loss of eggs in farm "A" was observed $21.23 \mathrm{~g}$ (Figure 1) being a multiple of 5 to $5.5 \mathrm{~g}$ found in farm "B" (Table 5). We assume that the cause of the great weight loss in farm " $\mathrm{A}$ " was the higher and inconstant temperature and relative humidity. Weight loss during incubation was only examined in farm "A", so farms were not compared regarding this trait. Weight loss during the 38 days of incubation was $14.72 \%$ in total. Gonzalez et al. (1999) measured $13.20 \%$ weight loss in medium-sized eggs. Hassan et al. (2005) declared $12.48 \%$ loss during 38 days in eggs stored for 5-10 
days and weighed $1515 \mathrm{~g}$. Nahm (2001) claimed that hatchability is negatively affected only if $20 \%$ weight loss is observed during incubation. Also El-Safty (2012) examined weight categories presented in Table 5 . He stated that surface area of eggs in the smallest weight category showed $543.30 \mathrm{~cm}^{2}$, in the medium and the largest category the surfaces were 572.30 and $598.80 \mathrm{~cm}^{2}$. There were significant differences between the categories. El-Safty (2012) did not find relationship between egg surface and porosity, nor in pores count $/ \mathrm{cm}^{2}$ and there was no difference between categories based on weight loss. He counted 26.9, 25.4 and 27.1 pores $/ \mathrm{cm}^{2}$ in small, medium and large eggs. Our results were closer to the 22 pores $/ \mathrm{cm}^{2}$ observed by Cloete et al. (2006). El-Safty (2012) stated that egg weight did not affect porosity significantly and the average pores count was in a medium, positive correlation with weight loss only in medium-sized eggs. Medium-sized eggs lost more water compared to small and large eggs. However, we found no difference in weight loss between eggs in each weight category.

\section{CONCLUSIONS}

In conclusion, we can summarize that except for egg length, a significant difference could be observed in all traits between trios. Narrower eggs showed smaller surface area, volume, circumference and shell volume and vice versa. Eggs from farm " $\mathrm{A}$ " indicated significantly greater width, shape index, surface area, circumference and shell volume than farm " $A$ ". Weight loss in farm " $A$ " was a multiple of farm " $B$ ", presumably due to the inappropriate storage conditions. In farm " $\mathrm{B}$ " there was a weak, positive correlation between storage period and egg weight loss $(r=0.22$, $\mathrm{P} \leq 0.05$ ). There was no relationship between initial egg weight and weight loss. We could demonstrate a weak, positive correlation between egg porosity and weight loss ( $\mathrm{r}=0.24, \mathrm{P} \leq 0.05)$. Pores count presented here was less than the international results. Poultry eggs contain the most pores on the blunt end, less via the equator and the least on the pointed end. In ostrich egg we found more pores via the equator against the blunt egg. To draw more precise conclusions further investigation should be carried out on porosity. Considering the fact that the length of storage period and the weight loss during incubation are in strict correlation with hatchability, we intend to extend our research aims to these traits.

\section{ACKNOWLEDGEMENTS}

The publication is supported by the EFOP-3.6.3VEKOP-16-2017-00008 project. The project is cofinanced by the European Union and the European Social Fund.

\section{REFERENCES}

Benoît, K.G.-Polycarpe, T.U.-Cyrille, B.-Loukyatou, B.-Larissat, F.-Ibath, C.-Nadia, E.-André, T. (2014): Egg physical quality and hatchability in captive African ostrich (Struthio camelus camelus, Linnaeus 1758) reared in Benin: Effect of season and relationships. International Journal of Advanced Research, 2:(6): 510-516.

Bogenfürst, F. (2017): Lúdtenyésztők kézikönyve. Fórum kiadó, 1340.

Brand, Z.-Brand, T.S.-Brown, C.R. (2003): The effect of different combinations of dietary energy and protein on the composition of ostrich eggs. South African Journal of Animal Science 33:(3):193-200.

Brand, Z.-Cloete, S.-Malecki, I.-Brown, C. (2014): Embryonic development in the ostrich (Struthio camelus) during the first 7 days of artificial incubation. British Poultry Science 55:(1):6875 .

Cloete, J.R.S.W.P.-Scholtz, A.J.-Brand, Z.-Cloete, S.W.P. (2006) A preliminary study on the application of image analysis for the measurement of ostrich eggshell traits. South African Journal of Animal Science 36: 155-159.

Cooper, R.G. (2001): Handling, incubation and hatchability of ostrich (Struthio camelus var. domesticus) eggs: A review. Journal of Applied Poultry Research 10:262-273.

Deeming, D.C. (1996): Production, fertility and hatchability of ostrich (Struthio camelus) eggs on a farm in the United Kingdom. Animal Science 63:329-336.

Denys, S.- Pieters, J.G.-Dewettinck, K. (2003): Combined CFD and experimental approach for determination of the surface heat transfer coefficient during thermal processing of eggs. Journal of Food Science, 68:3:943-951.
Elobeid, A.-Aisha, E.M.-El-Amin, A. (2010): Red-necked ostrich (Struthio camelus camelus) egg production, external characteristics and hatchability. International Journal of Sudan Research 1:(1):53-64.

El-Safty, S.A. (2012): Effect of egg weight grades, porosity and their interactions on some hatching traits of ostrich eggs. Egyptian Poultry Science 32:4:725-733.

Elsayed, M.A. (2009): Effect of month of production on external and internal ostrich egg quality, fertility and hatchability. Journal of Egyptian Poultry Science 29:(2):547-564.

Gefen, E.-Ar, A. (2001): Morphological description of the developing ostrich embryo: A tool for embryonic age estimation. Israel Journal of Zoology 47:(1):87-97.

Gonzalez, A.-Satterlee, D.G.-Moharer, F.-Cadd, G.G. (1999): Factors affecting ostrich egg hatchability. Poultry Science 78: 1257-1262.

Hassan, S.M.-Stam, A.A.-Mady, M.E.-Cartwright, A.I. (2005): Egg storage and weight effects on hatchability of ostrich (Struthio camelus) eggs. Physiology, endocrionology and reproduction, Poultry Science 84:1908-1912.

Koutinhouin, G.B.-Tougan, U.P.-Boko, C.-Baba, L.-Fanou, L.Chitou, I.B.-Everaert, N.-Thewis, A. (2014): Egg physical quality and hatchability in captive African Ostrich (Struthio camelus camelus, Linnaeus 1758) reared in Benin: effect of season and relationships. International Journal of Advanced Research 2:(6):510-516.

Moreki J.C.-Majuta, K. G.-Machete, J.B. (2016): External and internal characteristics of ostrich eggs from diabete ostrich farm. International Journal of Advanced Research 4:9:1397-1404. 
Mushi, E.Z.-Isa, J. W.-Binta, M.G.-Kgotlhane, M.C.G. (2007) Physical characteristics of ostrich (Struthio camelus) eggs from Botswana Journal of Animal and Veterinary Advances, 6:(5):676-677

Nahm, K.H. (2001): Effects of storage length and weight loss during incubation on the hatchability of ostrich eggs (Struthio camelus). Poultry Science 80:1667-1670.

Nedomová, Š.-Buchar, J. (2013): Ostrich eggs geometry. Acta Universitatis Agriculturae et Silviculturae Mendelianae Bruensis 61: (81):3:735-742.

Nedomová, Š.-Severa, L.-Buchar, J. (2009): Influence of hen egg shape on eggshell compressive strength. International Agrophysics, 23:3:249-256.
Perianu, C.-De Ketelaere, B.-Pluymers, B.-Desmet, W.-De Baerdemaeker, J.-Decuypere, E. (2010): Finite element approach for simulating the dynamic mechanical behaviour of a chicken egg. Biosystems Engineering, 106:79-85.

Selvan, S.T.-Gopi, H.-Natrajan, A.-Pandian, C.- Babu, M. (2014): Physical characteristics, chemical composition and fatty acid profile of ostrich eggs. International Journal of Environmental Science and Technology 3:(6):2242-2249. 
